\title{
Analysis of Interpersonal Communication in Sports
}

\author{
Ika Novitaria $\mathrm{M}$ \\ Pendidikan Kepelatihan Olahraga \\ Fakultas Ilmu Keolahragaan, \\ Universitas Negeri Jakarta \\ Jakarta, Indonesia \\ Ikanovi1979@gmail.com
}

\author{
Ari Subarkah \\ Pendidikan Kepelatihan Olahraga \\ Fakultas Ilmu Keolahragaan \\ Universitas Negeri Jakarta, \\ Jakarta, Indonesia \\ Ikanovi1979@gmail.com
}

\begin{abstract}
-human life is characterized by the dynamics of communication. The process of communication depends on the success rate in achievement of communication goals, that is, the extent to which a communicant conveys a message to communicators in order to get the same meaning. Effective communication can occur if both parties, that is, the sender and the recipient, have good skills in sending and receiving messages. Therefore, this study aims to provide an overview of how communication, especially verbal and nonverbal communication, is in sports. The research method used is a descriptive method with surveying techniques. The populations used are the players on futsal sports, hockey, football, basketball, and volleyball. The results showed that the most frequently used communication is nonverbal communication with $41 \%$ and verbal communication with $39 \%$. Therefore, non-verbal communication can control an interaction in a more precise way and can give emphasis to verbal messages.
\end{abstract}

Keywords-communication, verbal, nonverbal, sports

\section{INTRODUCTION}

As social beings, humans want to always be in touch with each other. If a person never communicates with others, he will feel isolated from his community. The effect of this isolation will lead to mental depression which ultimately leads to a loss of mental balance. Because communication can maintain and move life, it can turn instinct into inspiration through various processes and systems to ask, govern and supervise.

Communication is the process of delivering information from one person to another. It will go well, if the surrounding environment of mutual understanding arises, that is, when the two sides between the sender and the recipient can understand it [1]. According to Effendy [2], communication is a process of delivering an impression in the form of symbols and serves as a guide to thoughts and feelings in the form of ideas, information, feelings, hope, encouragement, confidence, and so on, which are performed by people indirectly through the media and one's goals to others face-to-face or changed attitudes, views, and behavior.

Communication has the objective to create a common understanding or to change the perception, even the behavior [3]. Because communication does not only convey information or messages, but communication is carried out by one another in an effort to form a meaning and carry out his hopes [4]. So it's important for people to trying to send message with clear and easily understood. Thus communication has a very important role in determining how effective people work together and coordinating efforts to achieve goals.

To be able to communicate effectively, people must consider the communication process that goes through, namely: communicator, communicant, message, channel and feedback [5]. Delivery of messages from the communicator to the communicant can be started from the most simple way by using sound and body movement, up to the most difficult way is to use language. Communication whose message is packaged verbally is called verbal communication, whereas communication whose message is packaged nonverbally is called nonverbal communication. Verbal communication is the delivery of meaning using words, while nonverbal communication does not use words [6].

Likewise in sports activities. Communication must occur in sports activities, especially in sports training. In carrying out the training process, communication is needed, especially in conveying messages between trainers and athletes, athletes with athletes or with other people such as parents. Communication is said to be effective if the communication that occurs causes a two-way information flow, that is with the appearance of feedback from the recipient of the message. Thus, the quality of training is also influenced by the effectiveness or not of the communication that occurs in the training activity.

Effective communication in training activities is a process of transforming messages in the form of science and technology from trainers to athletes. Athletes are able to understand the purpose of messages in accordance with their intended goals, so as to add insight into science and technology and lead to better behavioral changes. Submission of messages in sports can be done verbally or nonverbally. Moreover, the sport is a game. When an athlete performs the sport, he/she must frequently exchange information with both athletes and trainers. The usual exchange of information is more related to strategies or tactics and in terms of mentality.

This is reinforced by the research conducted by Fabienne D'Arripe Longueville, Jean F. Fournier, Alice Dubois, with tittle The Perceived Effectiveness of Interactions between Expert French Judo Coaches and Elite Female Athletes [7]. The results show that Coaches' and athletes' perceptions regarding their effective interactions and the underlying factors and reasons for effectiveness of these interactions were examined. There is also research conducted by Rakesh Kumar with tittle evaluation of interpersonal communication skills of the college students 
[8]. The results show that students' verbal communication skills need to be worked on. Students also need to speak with clarity and use non-aggressive, positive and formal tones. Their body language needs to change in order to give off a warm and assuring vibe to others.

The results of the research above show that Individuals with strong Interpersonal Communication Skills cope better with stress, handle major life transitions, and are less likely to suffer from depression and anxiety [9]. That's why in all companies and organizations, interpersonal communication determines whether a team can operate effectively and accomplish core business goal or not. Based on the above problems, the researchers are interested in researching the use of communication (verbal and nonverbal) in the sport.

\section{RESEARCH METHODOLOGY}

\section{A. Data Analysis Methods and Techniques}

The purpose of this research is to find out how the use of communication, both verbal and nonverbal, is in the sport. This research was carried out through several stages namely: Making proposals, collecting data and making research reports. The proposal was made at the Faculty of Sports Science, State University of Jakarta in March - April 2017. While the data collection was conducted at the sports venue, the game was held in July to August 2017. The last time the research report was made in the Faculty of Sports Science, Jakarta State University was from September to October 2017. The research approach used in this study is a qualitative approach [4] while the type of research used in this study is a type of descriptive research

\section{B. Subject}

The research population is the entire sport that is included in the category of sports games at the club of the Faculty of Sports Science, Jakarta State University. The sampling technique in this study was purposive sampling. The considerations taken are athletes from group games and those who return questionnaires according to the time specified, so that the samples in this study are futsal, football hockey, basketball and volleyball.

\section{Instrument Test}

The research instrument used to measure variables in this study about the use of communication in sports was by distributing and filling out questionnaires using the Guttman scale. The questionnaire used consists of two dimensions namely: verbal and non-verbal dimensions. The verbal dimension consists of Language, writing, words, praise and response. Whereas nonverbal dimension consists of sign or gesture, body movement, voice, style, facial expression, face contact, touch and picture.

\section{RESULT AND DISCUSSION}

\section{A. Result}

The results showed the data description which contained the number of sexes from the study subject, the lowest score empirical data, the highest score, median, mode, mean and standard deviation arising from the results of the questionnaire distribution. The following is a description of research data from several sports that were sampled in this study.

\section{TABLE I. DISTRIBUTION OF RESPONDENTS BY GENDER}

\begin{tabular}{|c|c|c|}
\hline Gender & Frequency & Percentage (\%) \\
\hline Woman & 47 & 57.33 \\
\hline Man & 32 & 42.67 \\
\hline Total & 75 & 100 \\
\hline
\end{tabular}

TABLE II. DESCRIPTION OF THE USES OF COMMUNICATION ON SPORTS

\begin{tabular}{|c|c|c|c|c|c|c|}
\hline No & Description & Futsal & Soccer & Hockey & $\begin{array}{c}\text { Basket } \\
\text { Ball }\end{array}$ & $\begin{array}{c}\text { Volley } \\
\text { Ball }\end{array}$ \\
\hline 1 & $\begin{array}{c}\text { Highest } \\
\text { Score }\end{array}$ & 17 & 21 & 18 & 10 & 10 \\
\hline 2 & $\begin{array}{c}\text { Lowest } \\
\text { Score }\end{array}$ & 28 & 29 & 28 & 30 & 30 \\
\hline 3 & Median & 25 & 25.5 & 24 & 22 & 25 \\
\hline 4 & Mean & 23.94 & 25.33 & 23.67 & 20.36 & 24.15 \\
\hline 5 & Modus & 25 & 24 & 23 & 22 & 25 \\
\hline 6 & SD & 87.13 & 108.05 & 72.25 & 59.07 & 205 \\
\hline
\end{tabular}

The results of this research showed that the most common communication in sports club coaching in game sports was nonverbal communication which was shown by the percentage of $41 \%$, while for verbal communication only $39 \%$. This shows that in coaching a sports club, communication that is carried out is non-verbal communication, because it can be carried out in the delivery of messages and can confirm verbal messages.

\section{B. Discussion}

The results of the above study indicate that nonverbal communication can control an interaction in a more appropriate and subtle way. With non-verbal communication one can emphasize nonverbal messages such as thumbs up to the players, which indicate that the coach is very happy with what the players do. When viewed based on the division of dimensions and indicators of verbal and nonverbal dimensions, it can be seen in the following discussion:

\section{Verbal}

Verbal communication is a form of communication conveyed by the communicator to the communicant in a written or oral way. Verbal communication occupies a large portion. Reality, ideas, thoughts or decisions, are easier to convey verbally rather than nonverbal. With hope, communicants (coaches and athletes) can more easily understand the messages delivered. Verbal communication has 5 (five) indicators, namely language, writing, words, praise and response.

The results of the study for Language indicators of respondents who answered YES were $71 \%$ and those who answered NO were $29 \%$. This means that when communicating in conduction of sports training, the use of language is carried out in conveying messages. For the second indicator, writing, the results show, respondents who 
answered YES are as much as $75 \%$ and those who answered $\mathrm{NO}$ as much as $25 \%$. This proves that writing can also be used as a communication medium between respondents with one another or respondents with the coach. It can also be used as one of the media in verbal communication in accomplishing ideas or feelings. With the help of writing, one's ideas or feelings can be known as a whole because the writing has a clear systematic with the help of the right choice of words and punctuation.

The results of the research for the third indicator, words, respondents who answered YES were as much as $63 \%$ and those who answered NO were $37 \%$. These results indicate that the communication that has occurred has chosen the right and appropriate words between the communicant and the communicator that is between the trainer and the athlete or vice versa. The choice of the words used has been understood and agreed upon, meaning the communication carried out can run well in the sport. The use of words and terms is in accordance with the agreement and understanding of the respondents. For the results of the study of praise indicators, the respondents who answered YES were as much as $89 \%$ and those who answered NO as much as $11 \%$. This shows that the respondent feels the coach gives praise in the form of statements, awards and recognition of what has been done by athletes. This is certainly very good and must be maintained, because praise can be a motivation for others to try better. Moreover, through praise, one can feel more appreciated, both from his efforts, kindness, or intelligence. It can also increase self-confidence, and can make other people happy, comfort the broken-hearted. Giving praise helps in making other people to see the positive side.

The results of the study for the response indicators, the respondents who answered YES are as much as $91 \%$ and those who answered NO as much as $9 \%$. This shows that in coaching in sports clubs there is a response from the coach to the athletes who are very good. The trainer responds according to what happens in the field. The response given is by doing what the athlete wants. With the response delivered from the trainer to the athlete or from the athlete to the trainer, it will neutralize the interpretation in a communication process.

\section{Nonverbal}

Nonverbal communication is a form of communication whose message is packaged in nonverbal form, without words. In communicating, almost automatically, nonverbal communication is used. Therefore, nonverbal communication is permanent and always available. It is more honest in expressing what you want to express because it's spontaneous. The following results will be discussed per indicator. The results of the study, for indicators Signs or signals of respondents who answered YES were $88 \%$ and those who answered NO were $12 \%$. This shows that the use of the sign or signals is done when there is communication between the trainer and the athlete. By using the sign or signal in communication, it can help to generate meaning. In addition, the use of signs in communicating can also replace verbal behavior, so without speaking we can interact with other people. For example, a musician comes to your car then without saying a word you shake your hand with your palm pointing forward (as a substitute for "No").

The results of the study for body language or movement indicators, respondents who answered YES are as much as $80 \%$ and those who answered NO were as much as $20 \%$. This shows that in nonverbal communication, body movement or language is also used intensively between trainers and athletes. Use of body language is needed when communicating, because body language can show us the emotional state of others. By using gestures or body language, we can get and provide more information about other people's feelings. For example, jumping after achieving success is considered a good way to display excitement. The results for the study of voice indicator showed that respondents who answered YES were as much as 91\% and those who answered NO as much as $9 \%$. The use of voice indicators in nonverbal communication in this case relates to loud or soft sound and high or low intonation of the voice issued by the person who is communicating. In sports, the use of sound is very necessary because sports are dynamic meaning they are always changing, especially when the game has begun, then a communicator who wants to convey his message makes a loud voice like shouting to call his friend's name so that he can pass the ball to him or maybe also when the coach wants to give encouragement by shouting "C'mon.. You Can Do It" with a voice that is so loud.

The results of the study for indicators of facial expression, respondents who answered YES were as much as $79 \%$ and those who answered NO as much as $21 \%$. This shows that there is the use of nonverbal communication through facial expressions in sports. Through facial expressions, we can recognize and understand the emotions of others. In addition to expressing emotions individually, it can also reveal a combination of emotions, such as a mixture of shock and sadness mixed with fear. The results of the study for indicators of eye contact, respondents who answered YES were as much as $87 \%$ and those who answered NO as much as $13 \%$. This shows that there is the use of nonverbal communication through eye contact. Like a statement from an ancient poet stating that "The eye is the window of the soul." This shows that eye contact and gaze provide social and emotional information. People often consciously or unconsciously engage in activities that involve eye contact. In some contexts, meeting two eyes evokes strong emotions.

The results of the study for touch indicators, the respondents who answered YES were as much as $68 \%$ and those who answered NO were $32 \%$. This shows that nonverbal communication also needs to be done in every sport because touch can be a clue to affection, caring, sexual interest, dominance, or aggression. Touch is a nonverbal behavior that has multi-meanings. In fact, this touch can be a slap, a punch, a pinch, a rub, a pat, a caress, a hug, a grip (hand position) or palpation to a soft touch at a glance. In sports, of course, this is needed to be able to increase motivation, affection and care. So, it is expected that by giving the right touch when communicating, it can improve sports performance. 


\section{CONCLUSION}

Communication is the process of delivering information from one person to someone else. Communication will work well if the surrounding environment arises from mutual understanding, that is, if both parties, the sender and the recipient of the message, can understand. Effective communication in training activities is the process of transforming messages in the form of science and technology from coaches to athletes or athletes to the coach. Communication can be done through verbal and nonverbal communication. From the results of the study, it is shown that the most common communication in sports club coaching in the game sports is nonverbal communication which is shown by the percentage of $41 \%$, while for verbal communication only gets $39 \%$. This shows that in coaching a sports club, communication is done is nonverbal communication, because it is carried out in the delivery of messages and can confirm verbal messages.

\section{REFERENCES}

[1] Widjaja. Ilmu Komunikasi. Bina Aksara: Jakarta, 2000

[2] Effendy, Onong Uchjana. Ilmu komunikasi teori dan praktek. PT. Remaja rosdakarya: Bandung, 2005

[3] Riant Nugroho D. Komunikasi Pemerintahan. Jakarta: Elek Media Komputindo Gramedia, 2004.

[4] Rusadi Ruslan. Metode Penelitian Public Relations dan Komunikasi. Jakarta: Grafindo Persada, 2003

[5] Fajar Marhaeni. Ilmu Komunikasi Teori dan Praktek. Yogyakarta: Graha Ilmu, 2009K. Elissa, "Title of paper if known," unpublished.

[6] Agus M. Hardjana. Komunikasi Intrapersonal dan Komunikasi Interpersonal. Yogyakarta: Kanisius, 2003

[7] Fabienne D'Arripe Longueville, Jean F. Fournier, Alice Dubois. The Perceived Effectiveness of Interactions Between Expert French Judo Coaches and Elite Female Athletes. Sport Psychologist, HumanKinetics, 1998, 12 (3), pp.317-332. <10.1123/tsp.12.3.317>. $<$ hal-01712645>

[8] Rakesh Kumar (2017), "I EVALUATION OF INTERPERSONAL COMMUNICATION SKILLS OF THE COLLEGE STUDENTS" International Journal of Marketing \& Financial Management, ISSN: $2348-3954$ (online) ISSN: $2349-2546$ (print), Volume 5,(Issue 6 , Jun-2017), pp 51-58,

[9] Segrin, G. \& Flora, J. (2000). Poor social skills are a vulnerability factor in the development of psychological problems. Human communication Research, 26(3) 489-514 